\title{
Structure and trends in climate parameters affecting winegrape production in northeast Spain
}

\author{
M. C. $\operatorname{Ramos}^{1, *}$, G. V. Jones ${ }^{2}$, J. A. Martínez-Casasnovas ${ }^{1}$ \\ ${ }^{1}$ Department of Environment and Soil Science, University of Lleida, Alcalde Rovira Roure 191, 25198 Lleida, Spain \\ ${ }^{2}$ Department of Environmental Studies, Southern Oregon University, Ashland, Oregon 97520, USA
}

\begin{abstract}
This study examined the structure and trends of climate parameters important to winegrape production from 1952 to 2006 in the Alt Penedès, Priorat, and Segrià regions of NE Spain. Average and extreme temperature and precipitation characteristics from 3 stations in the regions were organized into annual, growing season, and phenological growth stage periods and used to assess potential impacts on vineyard and wine quality, and changes in varietal suitability. Results show an overall growing season warming of 1.0 to $2.2^{\circ} \mathrm{C}$, with significant increases in heat accumulation indices that are driven mostly by increases in maximum temperature (average Tmax, number of days with Tmax $>$ 90th percentile, and number of days with $\operatorname{Tmax}>30^{\circ} \mathrm{C}$ ). Changes in many temperature parameters show moderate to strong relationships with vine and wine parameters in the 3 regions, including earlier phenological events concomitant with warmer growing seasons, higher wine quality with higher ripening diurnal temperature ranges, and reduced production in the warmest vintages. While trends in annual and growing season precipitation were not evident, precipitation during the bloom to véraison period declined significantly for all 3 sites, indicating potential soil moisture stress during this critical growth stage. Shorter-term analysis of crop evapotranspiration (ETc) reveals that the current impact per $1^{\circ} \mathrm{C}$ of growing season (Apr to Oct) warming is an increase in water demands in the region by 6 to $14 \%$. These observations, combined with climate projections, indicate potential disruption of climate-variety balance, increasing water stress, and challenges in producing quality wines without the adoption of appropriate adaptive measures.
\end{abstract}

KEY WORDS: Winegrapes $\cdot$ Wine $\cdot$ Bioclimatic indices $\cdot$ Climate change $\cdot$ Temperature $\cdot$ Precipitation

Resale or republication not permitted without written consent of the publisher

\section{INTRODUCTION}

Over the last few decades, many researchers have examined the nature and impacts of climate change in different regions of the world (Bonell \& Sumner 1992, Jones \& Conway 1997, Lee et al. 2000, Osborn et al. 2000, Kiktev et al. 2002, Salinger 2005), with particular focus on evaluating and predicting the impacts of climate change on different agricultural industries (e.g. Kenny et al. 1993, Jones \& Davis 2000, Chloupek et al. 2004, Rochette et al. 2004, Maracchi et al. 2005, Greene \& Maxwell 2007, Lobell 2007, Lobell et al. 2007, Todisco \& Vergni 2008). Depending on the sensitivity of the crop to climate, warming has the potential to bring about numerous risks and challenges that affect both the quality and quantity of production (Fischer et al.
2002). The need to further understand climate impacts on agriculture is accentuated by the fact that 7 of the 8 warmest years in the instrumental record of global surface temperatures have occurred since 2001 (including 2007) and the 10 warmest years have all occurred since 1997. Overall, the global average surface temperature has risen by 0.6 to $0.7^{\circ} \mathrm{C}$ since the start of the 20th century; however, the rate of increase in the last $25 \mathrm{yr}$ has been $>3$ times the century-scale trend (IPCC 2007).

While changes in average temperatures are evident and important, increasing attention is being paid to the analysis of extreme events, due to their potential impacts on human health (Díaz-Jiménez et al. 2005, Ebi et al. 2006) and agriculture (Easterling et al. 2000b, Martínez-Casasnovas et al. 2002, Michael et al. 2005). Extreme events are part of the inherent 
decadal fluctuation in the climate system, but they may also indicate longer-term trends related to anthropogenic climate change (Adams et al. 2001). On the other hand, changes in the frequency and distribution of precipitation are expected due to increased rates of the hydrological cycle, likely affecting water supplies for both urban and agricultural uses. In Europe, for example, Karl (1998), Beniston \& Tol (1998), Sumner et al. (2001), and Lana et al. (2003) showed decreasing rainfall trends or changes in seasonality of precipitation for much of the Mediterranean region. The interannual variability of the Mediterranean climate makes it difficult to assess tendencies in rainfall distribution patterns and potential impacts of climate change. Nevertheless, some recent studies point out significant changes in extreme events such as more frequent and extreme droughts, increases in cool-season precipitation, and warmseason drying (Easterling et al. 2000a,b, Ramos 2001, Sumner et al. 2001, Brunetti et al. 2002, Klein Tank \& Können 2003, Ramos \& Martínez-Casasnovas 2006a).

Climate change impacts across the agriculture sector will vary, depending on the crop and region. In particular, many perennial crops require both adequately cold periods for hardening and fruitfulness, and sufficiently warm periods to ripen quality fruit at economically sustainable levels without being overly stressed. One such crop system, Vitis vinifera winegrapes, provides a model system in which to monitor climate change impacts because of its long history, the narrow climate zones that individual varieties are best suited to, and the fact that wines have been obsessively tasted and rated for quality (Jones et al. 2005a).

Climate affects grapevine growth and fruit and wine production in many ways. During winter, grapewines need some dormant chilling to effectively set the latent buds for the coming vintage. During the growing season, grapevines need sustained average daily temperatures $>10^{\circ} \mathrm{C}$ to initiate growth, followed by sufficient heat accumulation to ripen fruits. However, temperature extremes during growth of the berries induce stress, premature véraison, berry abscission, enzyme activation, and cause less flavor development (Coombe 1987, Mullins et al. 1992). Frost occurrence and timing are also significant for grapevines which are favored by low frost risk in spring and fall, and a long frost-free season of 160 to $200 \mathrm{~d}$ or more. In terms of moisture requirements, grapevines ideally should start off the growing season with adequate soil moisture for initial growth, then receive nominal amounts (either naturally or via irrigation) throughout the growing season. However, many of these climatic ideals have been or will be pushed to their limits in many regions by climate change. Additionally, projected scenarios of warming imply earlier occurrence of phenological events and a compression of the growth period, which affect both wine production and quality (Webb et al. 2007).

Analyses of the impact of climate change on viticulture and wine production in Europe have suggested short-term benefits in terms of more consistent and higher quality production, with lower year-to-year variability (Kenny \& Harrison 1992, Jones et al. 2005a). However, despite these short-term benefits for growers, winemakers, and connoisseurs, the rise in global temperatures projected for the next half century may ultimately bode problems for the wine industry. Small changes in growing season temperatures could induce shifts in varietal suitability in many regions (Jones et al. 2005a) or necessitate costly adaptation measures both in the vineyard and in the winery. Furthermore, in regions such as Europe, where vines are not irrigated, either due to legal constraints or supply issues, changes in total rainfall or in its distribution throughout the year may have significant effects on water availability for plants, particularly during the warmer periods of the year.

In 2005, Spain was globally ranked first in area planted to winegrapes, with nearly 1.2 million ha, and third in production at nearly 35 million hl $(12.5 \%$ of world production), with the wine industry being one of the largest industries in the country (The Wine Institute; www.wineinstitute.org/resources/worldstatistics/ article126 and www.wineinstitute.org/resources/world statistics/article87. Spain has $\sim 100$ distinct wineproducing regions, with the majority being referred to as Denominaciones de Origen (DO) (similar to the French appellation controllée system) in which wine production is regulated for quality according to specific laws. Regions are classified as either Denominación de Origen Calificada (DOC; La Rioja and Priorat only), Denominación de Origen (DO; 67 regions), or Vinos de la Tierra (VdlT; numerous areas). Given the economic and cultural importance of the wine industry in Spain and the country's already warm to hot and dry climate for wine production, this research aims to examine the structure and trends in climate factors important to wine production in 3 significant wine production regions in Spain. The Catalonian region of NE Spain includes 11 DO wine production areas, with a vineyard area of about 115000 ha representing $18.5 \%$ of the total area planted with vines in Spain (Fig. 1). For this research, the areas studied include the most important producing areas of Alt Penedès (DO Alt Penedès and DO Cava), Priorat (DO Montsant and DOC Priorat), and Segrià (DO Costers del Segre). Vineyards represent $\sim 80,31$ and $3 \%$ of the total cultivated area in Alt Penedès, Priorat, and Segrià, respectively, and together produce a total of 2.4 million hl of wine (6\% of the total in Spain) (MAPA 2005). 


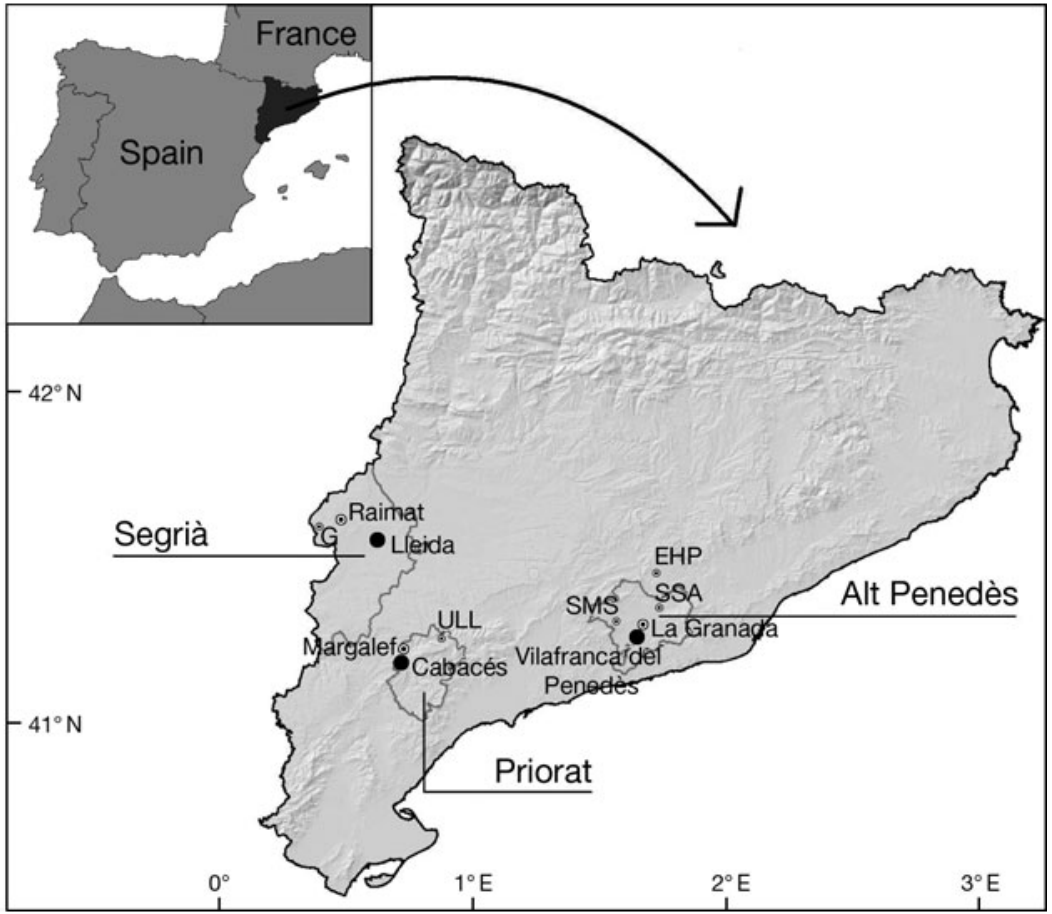

Fig. 1. Climate stations and wine producing regions: Alt Penedès - DO Penedès (Vilafranca del Penedès, Sant Sadurní d'Anoia [SSA], Sant Martí Sarroca [SMS], La Granada [LG], Els Hostalest de Pierola [EHP]); Priorat - DOC Priorat \& DO Montsant (Cabacès, Margalef, Ulldemolins [ULL]); and Segrià - DO Costers del Segre (Lleida, Raimat, Gimenells [G]) analysis (Fig. 1). Data for Vilafranca were obtained from INCAVI (Instituto Catalan de la viña y el vino) and for the other 2 stations from the Agencia Estatal de Meteorología. These were the only stations with sufficient records for longterm analysis. Furthermore, while these 3 stations do not capture microclimatic variation within the regions, they provide a good reference of the general structure and trends for temperature and precipitation in the DO Penedès, the DO Monsant, the important area of the DO Priorat, and the DO Costers del Segre in the subzone Raimat-Segrià. Shorter climatic series from the Agrometeorological Network of Catalonia comprising the stations Sant Sadurní d'Anoia (164 m), Els Hostales de Pierola (238 m), and Sant Martí Sarroca $(262 \mathrm{~m})$ in Alt Penedès; Margalef (405 m) and Ulldemolins (631 m) in Priorat; and Raimat (290 m) and Gimenells (248 m) in Segrià (Fig. 1) were examined and found to exhibit similar structure and trends for the last 10-12 yr to the longer series. This indicates that the 3 stations used in the analysis are representative of their respective regions (Ramos 2001, Ramos et al. 2007).

\section{DATA AND METHODS}

\subsection{Study areas and climate data}

This study was carried out using the longest available data series from 3 stations (Vilafranca del Penedès, Cabacès, and Lleida) in the Alt Penedès, Priorat, and Segrià, respectively (Fig. 1). The Penedès region covers an area of $\sim 1460 \mathrm{~km}^{2}$ and is located $\sim 30 \mathrm{~km}$ southwest of Barcelona, between the Sierra Prelitoral mountains and the Anoia and Llobregat rivers. The area is geologically part of the Penedès Tertiary Depression and winegrapes are typically grown over moderately sloping (average $10 \%$ ) land. The Priorat region is in a depression formed in the split of the southern part of the Montsant mountain chain with steeper sloped winegrape cultivation areas (typically $>40 \%$ ). Lleida is located in the Segrià region along the Segre River valley with more even terrain and where much of the wine production occurs on flat to gradual slopes. Daily rainfall and temperature (mean, maximum and minimum) recorded at Vilafranca del Penedès (1952-2006; elevation $223 \mathrm{~m})$, Cabacès (1967-2005 for temperature and 1952-2005 for precipitation; elevation $345 \mathrm{~m}$ ), and Lleida (1950-2006; elevation $199 \mathrm{~m}$ ) were used in the

\subsection{Climate parameters important for winegrape production}

Data from each station were organized into annual, growing season, or important grapevine growth periods and used to derive bioclimatic and extreme climate indices important for winegrape production (Table 1). For temperature; the average, maximum, and minimum values from each station were summarized for the growing season for winegrapes (April to October) since simple growing season averages explain much of the phenological development of grapevines, wine production, and quality (Jones et al. 2005a). In addition, temperature extremes were assessed as proposed by the Working Group on Climate Change Detection (Peterson et al. 2001) and include the annual number of days with minimum or maximum temperatures $>90$ th and <10th percentiles. Frost occurrence was assessed by examining the number of days with temperatures $<0^{\circ} \mathrm{C}$ and the length of the frost-free period. To assess temperature stress during the growth period, the number of days with temperatures $>25$ and $>30^{\circ} \mathrm{C}$ were determined (Jones \& Davis 2000). While temper- 
Table 1. Temperature and precipitation indices analyzed for each station

\begin{tabular}{|c|c|c|}
\hline No. & Variable & Description \\
\hline \multicolumn{3}{|c|}{ Temperature indices } \\
\hline 1 & GSTavg & Average growing season temperature (April to October) \\
\hline 2 & GSTmax & $\begin{array}{l}\text { Average growing season maximum temperature } \\
\text { (April to October) }\end{array}$ \\
\hline 3 & GSTmin & $\begin{array}{l}\text { Average growing season minimum temperature } \\
\text { (April to October) }\end{array}$ \\
\hline 4 & NDTmin90p & $\begin{array}{l}\text { Annual number of days with minimum temperature } \\
>90 \text { th percentile }\end{array}$ \\
\hline 5 & NDTmax90p & $\begin{array}{l}\text { Annual number of days with maximum temperature } \\
>90 \text { th percentile }\end{array}$ \\
\hline 6 & NDTmin $10 p$ & $\begin{array}{l}\text { Annual number of days with minimum temperature } \\
<10 \text { th percentile }\end{array}$ \\
\hline 7 & NDTmax10p & $\begin{array}{l}\text { Annual number of days with maximum temperature } \\
<10 \text { th percentile }\end{array}$ \\
\hline 8 & FD & $\begin{array}{l}\text { Frost occurrence; number of days with minimum tem- } \\
\text { perature }<0^{\circ} \mathrm{C}\end{array}$ \\
\hline 9 & FFL & $\begin{array}{l}\text { Frost-free period length; number of days between dates } \\
\text { with temperature }<0^{\circ} \mathrm{C}\end{array}$ \\
\hline 10 & ND25 & Number of days with Tmax $>25^{\circ} \mathrm{C}$ \\
\hline 11 & ND30 & $\begin{array}{l}\text { Number of days with } \mathrm{Tmax}>30^{\circ} \mathrm{C} \text {, critical temperature } \\
\text { for optimum growth }\end{array}$ \\
\hline 12 & WI & $\begin{array}{l}\text { Winkler Index (Winkler et al. 1974) (see Section 2.2, this } \\
\text { page) }\end{array}$ \\
\hline 13 & $\mathrm{HI}$ & Huglin Index (Huglin 1978) (see Section 2.2, this page) \\
\hline 14 & DTR & $\begin{array}{l}\text { Daily temperature range during ripening (Tmax-Tmin; } \\
\text { August and September) }\end{array}$ \\
\hline \multicolumn{3}{|c|}{ Precipitation indices } \\
\hline 1 & Pannual & Total annual precipitation \\
\hline 2 & Pgs & Total growing season precipitation (April to October) \\
\hline 3 & Pmax & Maximum $1 \mathrm{~d}$ precipitation total \\
\hline 4 & & Rainfall during \\
\hline & P-I & Stage I: budbreak to bloom-April 1 to May 10 \\
\hline & P-II & Stage II: bloom to véraison - May 11 to June 30 \\
\hline & P-III & $\begin{array}{l}\text { Stage III: ripening (véraison to harvest) - July } 1 \text { to } \\
\text { September } 15\end{array}$ \\
\hline & $\begin{array}{l}\text { P-IV } \\
\text { P-V }\end{array}$ & $\begin{array}{l}\text { Stage IV: post harvest - September } 15 \text { to October } 31 \\
\text { Stage V: dormant period — November } 1 \text { to April } 1\end{array}$ \\
\hline 5 & NP95p & $\begin{array}{l}\text { Number of days with precipitation }>95 \text { th percentile } \\
\text { (very wet days) }\end{array}$ \\
\hline 6 & \%P95p & $\begin{array}{l}\text { Percentage of annual precipitation recorded on very wet } \\
\text { days }\end{array}$ \\
\hline 7 & DPL & Maximum annual drought period \\
\hline
\end{tabular}

ture and subtracting a base of $10^{\circ} \mathrm{C}$ (the minimum at which vine growth occurs) and multiplying by the number of days in the month:

$$
\mathrm{WI}=\sum_{\text {April }}^{\text {Oct }}(\mathrm{Tm}-10)
$$

where $T m$ is the average daily temperature.

(2) Huglin Index for April to September (Huglin 1978) gives more weight to maximum temperatures; calculated as

$$
\mathrm{HI}=\sum_{\text {April }}^{\text {Sept }} K \frac{(\mathrm{Tm}-10)+(\mathrm{T} \max -10)}{2}
$$

where Tm is the average daily temperature, Tmax is the maximum daily temperature and $K$, is the length of day coefficient, varying from 1.02 to 1.06 at 40 to $50^{\circ} \mathrm{N}$.

These 2 bioclimatic indices, which are based on variations in growing degreedays, are the most widely utilized measures of spatial suitability for viticulture and provide general guidelines on wine style or potential quality (Jones et al. 2005b, Blanco-Ward et al. 2007).

Finally, the diurnal temperature range (DTR) during the ripening months of August and September was calculated as DTR $=$ Tmax - Tmin to examine trends that influence important quality factors such as composition, flavor, and aroma (Mullins et al. 1992).

Given the low rainfall regimes in these regions, the precipitation parameters were averaged through different periods to assess the overall availability of water for grapevine growth. The station precipitation data were averaged by annual, growing season, and grapevine growth stages in the region as given by Hidalgo (2002) (Table 1). Precipitation extremes were assessed as proposed by the Working Group on Climate Change Detection (Peterson et atures $\sim 25^{\circ} \mathrm{C}$ are considered optimum for grapevine photosynthesis and growth (Coombe 1987), prolonged periods at temperatures $>30^{\circ} \mathrm{C}$ can induce heat stress, premature véraison, berry abscission, enzyme activation and cause less flavor development (Mullins et al. 1992). Other temperature-based variables derived for further analysis include:

(1) Winkler Index for April to October (Winkler et al. 1974) calculated by taking the mean monthly tempera- al. 2001) and include the maximum one-day precipitation total, the annual number of days with precipitation $>95$ th percentile (very wet days), the percentage of annual precipitation recorded on very wet days, and the maximum annual drought period length (maximum number of consecutive days without rainfall within a year).

The 25 variables were evaluated by basic descriptive statistics and, since some of the parameters examined 
were normally distributed while others deviated slightly from normality, a more stringent nonparametric Mann-Kendall trend test (MK-test) was applied to all series (Hirsch et al. 1991). In addition, the time series were assessed for autocorrelation using the Durbin-Watson statistic. Since ca. one-half of the time series had autocorrelation, we applied a conditional Mann-Kendall trend test with a $95 \%$ significance level (Hirsch et al. 1991, Libiseller \& Grimvall 2002), which provides a more conservative trend significance test in the presence of autocorrelation. We also confirmed the results of the present analysis by doing a prewhitening (lagged regression in the time domain) of the series to avoid power loss in the MK-test, as proposed by von Storch (1995), Douglas et al. (2000) and Zhang et al. (2001) and analysed by Bayazit \& Önöz (2007). An ARIMA model was used for prewhitening and the MKtest was applied to the series to assess the significance of the trends. Prewhitening effectively decreases the probability of rejecting the null hypothesis in the MKtest and all trends in this analysis were significant at $95 \%$. In addition, the precipitation data were assessed using the Alexandersson test for time series homogeneity (Alexandersson 1986).

Given the semi-arid climate of the region and low summer rainfall regimes, the research also examined evapotranspiration (ET) characteristics and trends. Hourly data with ET parameters were limited to 3 other climate stations in the region from the Agrometerological Network of Catalonia. These stations are very close to the other stations included in the longer series analysis (see above), and include Raimat (290 m, in the Segrià area), Margalef (405 m, in the Priorat), and La Granada (238 m, in the Penedès area). Data for each station were obtained for 1996-2007 and include hourly values of temperature, precipitation, humidity, wind speed and direction, pressure, solar radiation, and reference ET (ETo), calculated using the PenmanMonteith equation. The daily crop ET (ETc) was estimated using the Kc coefficients proposed by the Food and Agricultural Organization (Allen et al. 1998).

\subsection{Grapevine, wine quality and production data}

To examine relationships of climate trends with grapevine and wine parameters, data from the 3 regions were accessed from several sources. For the DO Penedès, phenology data were obtained for 19962007 from numerous growers, and include bud break, bloom, véraison, and harvest dates for some of the main varieties grown in the region (Macabeo, Xarello, Parellada, Chardonnay, and Pinot Noir). DO Penedès wine quality ranks given annually (1962-2006) by the Consejo Regulador de la DO Penedès (regulatory council) for both white and red wines from the region were also obtained. The ranks are an overall assessment of the vintage from the region and are given 'poor' to 'excellent' ranks which were coded 1 to 5 for analysis. Production data (in hl) for 1994-2007 for the DO Penedès were also obtained from the regulatory council (www.dopenedes.es) as well as production data $\left(\mathrm{kg} \mathrm{ha}^{-1}\right)$ from 2 producers for Macabeo, Parellada, Chardonnay and Xarello.

The DOC Priorat grapevine phenology and production data were limited to only a few years and were not assessed. However, red wine quality rank data were obtained from the Consejo Regulador de la DOC Priorat for 1960-2006 (www.doqpriorat.org). The quality ranks have the same nominal classes as described for the DO Penedès and were converted to the same numerical ranks for analysis. DOC Priorat production data were insufficient for this analysis.

For the DO Costers del Segre, harvest dates were obtained from a producer network for 16 varieties grown in the region; however, only 8 varieties had complete records over the 1997-2007 time period (Cabernet Sauvignon, Chardonnay, Macabeo, Merlot, Parellada, Pinot Noir, Tempranillo, and Xarello). The DO Costers del Segre quality and production data were limited to only a few years and were not assessed.

\section{RESULTS}

\subsection{Regional climate structure}

The general climate for the Alt Penedès is temperate to maritime Mediterranean with an annual average temperature of $15^{\circ} \mathrm{C}\left(9\right.$ to $25^{\circ} \mathrm{C}$ ) and annual average rainfall of $\sim 550 \mathrm{~mm}$, mainly in spring and autumn. The climate in the Priorat region is classified as Mediterranean temperate with a trend to continental and is characterized by dry NE wind flow and an annual average temperature of $15^{\circ} \mathrm{C}\left(6\right.$ to $\left.23^{\circ} \mathrm{C}\right)$. Average rainfall is $\sim 500 \mathrm{~mm}$, mainly in the spring and autumn. The Segrià region's climate is continental-subarid, characterized by high seasonal temperature variability, cold winters and hot summers (annual average temperature $\sim 15^{\circ} \mathrm{C}$, range 0 to $23^{\circ} \mathrm{C}$ ), and average annual rainfall of $\sim 350 \mathrm{~mm}$, mainly in spring and autumn.

For winegrape maturity potential, the locations are considered warm $\left(18.8^{\circ} \mathrm{C}\right.$ for Vilafranca del Penedès) to hot (19.4 and $19.6^{\circ} \mathrm{C}$ for Cabacès and Lleida) based on growing season average temperatures (GSTavg) (Table 2) (Jones 2006). While variability in GSTavg is similar across the 3 locations, GSTmax (growing season maximum temperature), GSTmin (growing season minimum temperature), and temperature extremes (10th and 90th percentiles) are more pronounced for 
Table 2. Descriptive and conditional Mann-Kendall test statistics after prewhitening for the temperature climate variables for the 3 meteorological stations Vilafranca del Penedès (1952-2006), Cabacès (1967-2005), and Lleida (1960-2006). Climate variables and their abbreviations are described in Table 1. Bold numbers indicate significant trends at $\geq 95 \%$ level

\begin{tabular}{|c|c|c|c|c|c|c|}
\hline Station & Variable & Mean & SD & $\begin{array}{c}\text { Trend } \\
\mathrm{yr}^{-1}\end{array}$ & $\begin{array}{c}\text { MK- } \\
\text { test }\end{array}$ & $\mathrm{p}$ \\
\hline \multirow{14}{*}{$\begin{array}{l}\text { Vilafranca } \\
\text { del Penedès } \\
\text { (Alt Penedès) }\end{array}$} & GSTavg $\left({ }^{\circ} \mathrm{C}\right)$ & 18.8 & 1.0 & 0.04 & 2.59 & 0.009 \\
\hline & GSTmax $\left({ }^{\circ} \mathrm{C}\right)$ & 24.0 & 1.3 & 0.04 & 2.05 & 0.040 \\
\hline & $\operatorname{GSTmin}\left({ }^{\circ} \mathrm{C}\right)$ & 13.5 & 0.9 & 0.03 & 2.88 & 0.004 \\
\hline & NDTmin90p $\left(7.9^{\circ} \mathrm{C}\right)$ & 14.4 & 12.8 & 0.52 & 1.99 & 0.046 \\
\hline & NDTmax90p $\left(18.6^{\circ} \mathrm{C}\right)$ & 8.0 & 6.2 & 0.20 & 3.48 & 0.001 \\
\hline & NDTmin $10 \mathrm{p}\left(-0.2^{\circ} \mathrm{C}\right)$ & 8.5 & 6.1 & -0.06 & -2.16 & 0.030 \\
\hline & NDTmax10p $\left(9.3^{\circ} \mathrm{C}\right)$ & 13.8 & 8.9 & -0.26 & -1.96 & 0.049 \\
\hline & FD (days) & 12.5 & 7.8 & -0.18 & -1.88 & 0.060 \\
\hline & FFL (days) & 288.0 & 65.0 & 0.22 & 0.48 & 0.633 \\
\hline & ND25 (days) & 90.0 & 20.5 & 1.67 & 2.69 & 0.007 \\
\hline & ND30 (days) & 17.8 & 10.9 & 0.43 & 2.78 & 0.005 \\
\hline & WI (Apr-Oct, $\left.10^{\circ} \mathrm{C}\right)$ & 1860 & 202 & 7.81 & 2.59 & 0.009 \\
\hline & $\mathrm{HI}$ (Apr-Sept, $\left.10^{\circ} \mathrm{C}\right)$ & 2196 & 186 & 7.23 & 3.09 & 0.002 \\
\hline & DTR (Aug-Sept, $\left.{ }^{\circ} \mathrm{C}\right)$ & 10.1 & 0.8 & 0.01 & 0.28 & 0.782 \\
\hline \multirow{14}{*}{$\begin{array}{l}\text { Cabacès } \\
\text { (Priorat) }\end{array}$} & GSTavg $\left({ }^{\circ} \mathrm{C}\right)$ & 19.4 & 1.0 & 0.05 & 2.31 & 0.021 \\
\hline & $\operatorname{GSTmax}\left({ }^{\circ} \mathrm{C}\right)$ & 24.9 & 1.3 & 0.06 & 2.12 & 0.034 \\
\hline & $\operatorname{GSTmin}\left({ }^{\circ} \mathrm{C}\right)$ & 13.9 & 1.0 & 0.04 & 1.49 & 0.137 \\
\hline & NDTmin90p $\left(20.0^{\circ} \mathrm{C}\right)$ & 21.3 & 10.5 & 0.57 & 2.21 & 0.027 \\
\hline & NDTmax $90 \mathrm{p}\left(31.4^{\circ} \mathrm{C}\right)$ & 32.3 & 14.9 & 1.04 & 1.96 & 0.050 \\
\hline & NDTmin $10 \mathrm{p}\left(2.0^{\circ} \mathrm{C}\right)$ & 36.6 & 13.8 & -0.13 & -0.30 & 0.760 \\
\hline & NDTmax10p $\left(9.5^{\circ} \mathrm{C}\right)$ & 45.7 & 17.8 & -1.06 & -1.51 & 0.013 \\
\hline & $\mathrm{FD}(\mathrm{d})$ & 16.1 & 10.5 & -0.03 & -0.98 & 0.326 \\
\hline & FFL (d) & 266.0 & 36.0 & 0.89 & 1.39 & 0.161 \\
\hline & ND25 (d) & 107.6 & 17.2 & 0.99 & 2.82 & 0.005 \\
\hline & ND30 (d) & 42.4 & 16.5 & 1.12 & 2.29 & 0.022 \\
\hline & WI (Apr-Oct, $\left.10^{\circ} \mathrm{C}\right)$ & 2039 & 202 & 11.24 & 2.29 & 0.022 \\
\hline & $\mathrm{HI}\left(\mathrm{Apr}-\mathrm{Sept}, 10^{\circ} \mathrm{C}\right)$ & 2444 & 191 & 11.92 & 2.60 & 0.009 \\
\hline & DTR (Aug-Sept, $\left.{ }^{\circ} \mathrm{C}\right)$ & 10.8 & 0.8 & 0.06 & 1.89 & 0.057 \\
\hline \multirow{14}{*}{$\begin{array}{l}\text { Lleida } \\
\text { (Segrià) }\end{array}$} & GSTavg $\left({ }^{\circ} \mathrm{C}\right)$ & 19.6 & 0.8 & 0.02 & 1.58 & 0.115 \\
\hline & $\operatorname{GSTmax}\left({ }^{\circ} \mathrm{C}\right)$ & 26.5 & 1.0 & 0.05 & 2.43 & 0.015 \\
\hline & $\operatorname{GSTmin}\left({ }^{\circ} \mathrm{C}\right)$ & 13.0 & 0.7 & -0.01 & -0.68 & 0.497 \\
\hline & NDTmin90p $\left(17.8^{\circ} \mathrm{C}\right)$ & 36.9 & 14.6 & -0.13 & 0.63 & 0.527 \\
\hline & NDTmax $90 \mathrm{p}\left(32.4^{\circ} \mathrm{C}\right)$ & 36.6 & 12.1 & 0.52 & 2.28 & 0.022 \\
\hline & NDTmin $10 \mathrm{p}\left(4.8^{\circ} \mathrm{C}\right)$ & 39.6 & 13.8 & 0.19 & 0.96 & 0.336 \\
\hline & NDTmax $10 \mathrm{p}\left(9.8^{\circ} \mathrm{C}\right)$ & 41.4 & 14.5 & -0.68 & -2.25 & 0.025 \\
\hline & $\mathrm{FD}(\mathrm{d})$ & 35.7 & 14.0 & 0.31 & 0.77 & 0.441 \\
\hline & FFL (d) & 246.0 & 33.0 & 0.13 & 0.14 & 0.891 \\
\hline & ND25 (d) & 127.7 & 19.0 & 0.54 & 2.91 & 0.004 \\
\hline & ND30 (d) & 64.3 & 15.1 & 0.78 & 2.71 & 0.007 \\
\hline & WI (Apr-Oct, $\left.10^{\circ} \mathrm{C}\right)$ & 2052 & 135 & 3.30 & 1.62 & 0.104 \\
\hline & $\mathrm{HI}\left(\mathrm{Apr}-\mathrm{Sept}, 10^{\circ} \mathrm{C}\right)$ & 2588 & 164 & 6.09 & 2.43 & 0.015 \\
\hline & DTR (Aug-Sept, $\left.{ }^{\circ} \mathrm{C}\right)$ & 13.6 & 1.3 & 0.04 & 2.25 & 0.025 \\
\hline
\end{tabular}

the 2 more inland areas (Cabacès and Lleida) than for the coastal area of Vilafranca del Penedès (Fig. 1). The number of days with temperatures $<0^{\circ} \mathrm{C}$ was highest in Lleida $(35.7 \mathrm{~d})$ and the lowest in Vilafranca del Penedès $(12.5 \mathrm{~d})$. The frost-free period was longest for Vilafranca del Penedès averaging $288 d$, followed by Cabacès with 266 d, and Lleida with 246 d (Table 2). The number of days during the growing season with temperatures $>25$ and $30^{\circ} \mathrm{C}$ also follows the coastal to inland structure with Vilafranca del Penedès experiencing fewer overall days (90 and 18, respectively) while Lleida experienced $>125 \mathrm{~d}$ with temperatures $>25^{\circ} \mathrm{C}$ and $60 \mathrm{~d}$ with temperatures $>30^{\circ} \mathrm{C}$ per vintage.

Average degree-day values (WI) total 1860, 2039 and 2052 for Vilafranca del Penedès, Cabacès, and Lleida, respectively (Table 2). These values place Vilafranca del Penedès in Winkler region III, which indicates generally favorable climates for high production of good quality table wines (Winkler et al. 1974). The values for Cabacès and Lleida place them in Winkler region IV, which is also favorable for high production, although experiences in California indicate that production of table wine quality may be hindered in this Winkler region due to excess heat. Average Huglin Index values, which may be more appropriate than the WI for European regions (Blanco-Ward et al. 2007), were 2196, 2444 and 2588 for Vilafranca del Penedès, Cabacès, and Lleida, respectively (Table 2). These values place Vilafranca del Penedès in Huglin's temperate climate type suitable for Cabernet Sauvignon and Merlot, for example (Huglin 1978). Cabacès and Lleida values are in Huglin's warm temperate and warm climate types and should be more suitable for Grenache, Syrah, and Carignane. The ripening period DTR reveals similar average values $\left(10.1\right.$ and $\left.10.8^{\circ} \mathrm{C}\right)$ and variability $\left(0.8^{\circ} \mathrm{C}\right)$ for Vilafranca del Penedès and Cabacès, while Lleida had a greater DTR and variation $\left(13.6 \pm 1.3^{\circ} \mathrm{C}\right)$ that is indicative of its more inland location.

Precipitation values indicate semiarid conditions with annual amounts totaling 362, 524 and $538 \mathrm{~mm}$ for Lleida, Vilafranca del Penedès, and Cabacès, respectively (Table 3). Precipitation variability over the time period indicates that each site experienced $\sim 25$ to $30 \%$ variation in most years. Growing season (Apr to Oct) precipitation shows similar average structure with Lleida $(235 \mathrm{~mm})$ being drier than Cabacès $(328 \mathrm{~mm})$ or Vilafranca del Penedès (331 $\mathrm{mm})$, although annual variability was higher. During the growing season, precipitation extremes in terms of maximum 1 d precipitation events averaged 3 to 4 times higher at the more coastal location, Vilafranca 
Table 3. Descriptive and conditional Mann-Kendall test statistics for the precipitation climate variables for the 3 meteorological stations Vilafranca del Penedès (1952-2006), Cabacès (1952-2005), and Lleida (1960-2006). Climate variables and their abbreviations are described in Table 1 . Bold numbers indicate significant trends at $\geq 95 \%$ level

\begin{tabular}{|c|c|c|c|c|c|c|}
\hline Station & Variable & Mean & $\mathrm{SD}$ & $\begin{array}{c}\text { Trend } \\
\mathrm{yr}^{-1}\end{array}$ & $\begin{array}{l}\text { MK- } \\
\text { test }\end{array}$ & $\mathrm{p}$ \\
\hline \multirow{11}{*}{$\begin{array}{l}\text { Vilafranca } \\
\text { del Penedès } \\
\text { (Alt Penedès) }\end{array}$} & Pannual (mm) & 524.2 & 118.5 & 0.66 & 0.33 & 0.744 \\
\hline & Pgs (mm) & 331.4 & 106.8 & -0.29 & 0.04 & 0.960 \\
\hline & Pmax (mm) & 124.0 & 21.0 & 0.35 & 0.25 & 0.307 \\
\hline & NP95p (d) & 3.1 & 1.8 & 0.01 & 0.76 & 0.012 \\
\hline & \%P95p (\%) & 27.3 & 25.3 & 0.03 & 0.32 & 0.032 \\
\hline & DPL (d) & 41 & 11.5 & 0.26 & 0.11 & 0.913 \\
\hline & P-I (mm) & 56.1 & 40.6 & 0.43 & 0.57 & 0.571 \\
\hline & P-II (mm) & 60.7 & 37.5 & -0.33 & -1.98 & 0.050 \\
\hline & P-III (mm) & 92.6 & 58.5 & 0.02 & 1.21 & 0.225 \\
\hline & P-IV (mm) & 106.8 & 78.5 & 0.14 & 0.65 & 0.518 \\
\hline & $\mathrm{P}-\mathrm{V}(\mathrm{mm})$ & 191.6 & 80.3 & -0.06 & -0.33 & 0.743 \\
\hline \multirow{11}{*}{$\begin{array}{l}\text { Cabacès } \\
\text { (Priorat) }\end{array}$} & Pannual (mm) & 538.3 & 128.4 & -0.56 & -0.32 & 0.748 \\
\hline & Pgs (mm) & 327.9 & 119.8 & -0.30 & -0.23 & 0.818 \\
\hline & Pmax (mm) & 68.1 & 34.3 & 0.07 & -0.96 & 0.340 \\
\hline & NP95p (d) & 3.8 & 2.0 & -0.01 & -0.10 & 0.910 \\
\hline & \%P95p (\%) & 12.0 & 5.8 & 0.01 & -0.46 & 0.649 \\
\hline & DPL (d) & 43 & 13.3 & 0.19 & 0.84 & 0.399 \\
\hline & P-I (mm) & 71.6 & 50.5 & 1.02 & 2.74 & 0.006 \\
\hline & P-II (mm) & 87.9 & 65.5 & -1.25 & -2.43 & 0.015 \\
\hline & P-III (mm) & 59.2 & 40.2 & 0.01 & 0.27 & 0.778 \\
\hline & P-IV (mm) & 108.5 & 85.2 & 0.01 & -0.53 & 0.596 \\
\hline & $\mathrm{P}-\mathrm{V}(\mathrm{mm})$ & 134.2 & 83.1 & 0.46 & 2.78 & 0.645 \\
\hline \multirow{11}{*}{$\begin{array}{l}\text { Lleida } \\
\text { (Segrià) }\end{array}$} & Pannual (mm) & 362.0 & 5.6 & -1.29 & -1.29 & 0.196 \\
\hline & Pgs (mm) & 235.0 & 76.2 & -0.65 & -0.18 & 0.857 \\
\hline & Pmax (mm) & 37.7 & 1.1 & 0.08 & 0.89 & 0.373 \\
\hline & NP95p (d) & 1.5 & $\begin{array}{r}1.1 \\
12.8\end{array}$ & 0.01 & 0.50 & 0.626 \\
\hline & \%P95p (\%) & 34.8 & 3.5 & 0.30 & 1.20 & 0.231 \\
\hline & DPL (d) & 43 & 14.4 & -0.14 & -0.35 & 0.726 \\
\hline & P-I (mm) & 54.8 & 33.2 & 0.55 & 1.80 & 0.072 \\
\hline & P-II (mm) & 64.2 & 43.2 & -0.91 & -2.19 & 0.028 \\
\hline & P-III (mm) & 53.4 & 32.4 & -0.29 & -0.50 & 0.616 \\
\hline & P-IV (mm) & 65.6 & 10.9 & 0.26 & 0.54 & 0.589 \\
\hline & P-V (mm) & 111.5 & 56.0 & -0.72 & -1.26 & 0.208 \\
\hline
\end{tabular}

del Penedès, compared to the other 2 sites (Table 3 ). The 3 sites experienced on average $1-4 \mathrm{~d}$ of precipitation events in the 95th percentile, with Lleida experiencing $\sim 35 \%$ of its annual rainfall in these events compared to only 27 and $12 \%$ for Vilafranca del Penedès and Cabacès, respectively. However, these events in the 95th percentile were usually of high intensity and short duration in Vilafranca and Cabacès, but were of higher duration and less intensity in Lleida. Even with some evidence of a coastal-inland location influence, the maximum annual drought period length (DPL) was similar across all 3 sites (41-43 d) due to a dry summer regime.

Precipitation values during the phenological stages were highest during the dormant period (winter) for all locations and limited during the main growing stages (Table 3). During Stage I (bud break to bloom), when grapevines need sufficient soil moisture for early season growth, rainfall in these regions was sparse ranging from 54.8 to $71.6 \mathrm{~mm}$. From bloom to véraison (Stage II), Cabacès received slightly more precipitation than the other 2 locations, while Vilafranca del Penedès received the most during véraison to harvest (Stage III). Precipitation during the post-harvest period (Stage IV), when the vines are beginning to go into dormancy, picked up in both Vilafranca del Penedès and Cabacès, while remaining relatively low in inland Lleida (Table 3). Precipitation variability was quite high (60 to $80 \%$ of the averages) across phenological stages.

\subsection{Temperature parameter trends}

Growing season average temperatures increased for the 3 stations, driven mainly by more significant changes in maximum temperatures (Table 2, Fig. 2). Average temperature trends

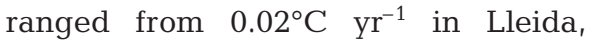
$0.04^{\circ} \mathrm{C} \mathrm{yr}^{-1}$ in Vilafranca del Penedès, to $0.05^{\circ} \mathrm{C} \mathrm{yr}^{-1}$ in Cabacès. Rates of warming, average growing season maximum (GSTmax) and minimum (GSTmin) temperatures were significantly higher for both Vilafranca del Penedès and Cabacès, while Lleida exhibited significant changes only in GSTmax (Fig. 2). Overall warming in growing season average temperatures ranged from 1.0 to $2.2^{\circ} \mathrm{C}$ for the 3 locations over their respective time periods. Similar results were also found in other European wine regions (Jones et al. 2005b) with growing seasons warming by $1.7^{\circ} \mathrm{C}$ on average over the last $30-$ 50 yr. For Spain, Jones et al. (2005b) reported an average growing season warming of $0.8-1.2^{\circ} \mathrm{C}$ for Galicia (Miño river valley) and Castilla y León (Valladolid).

Similar to average growing season temperatures, the number of days with temperatures >90th percentile increased significantly for both maximum and minimum temperatures in Vilafranca del Penedès and Cabacès, the stations with more maritime influence, while significant increases were seen only for maximum temperatures in Lleida (more inland location). For the number of days with temperatures $<10$ th per- 

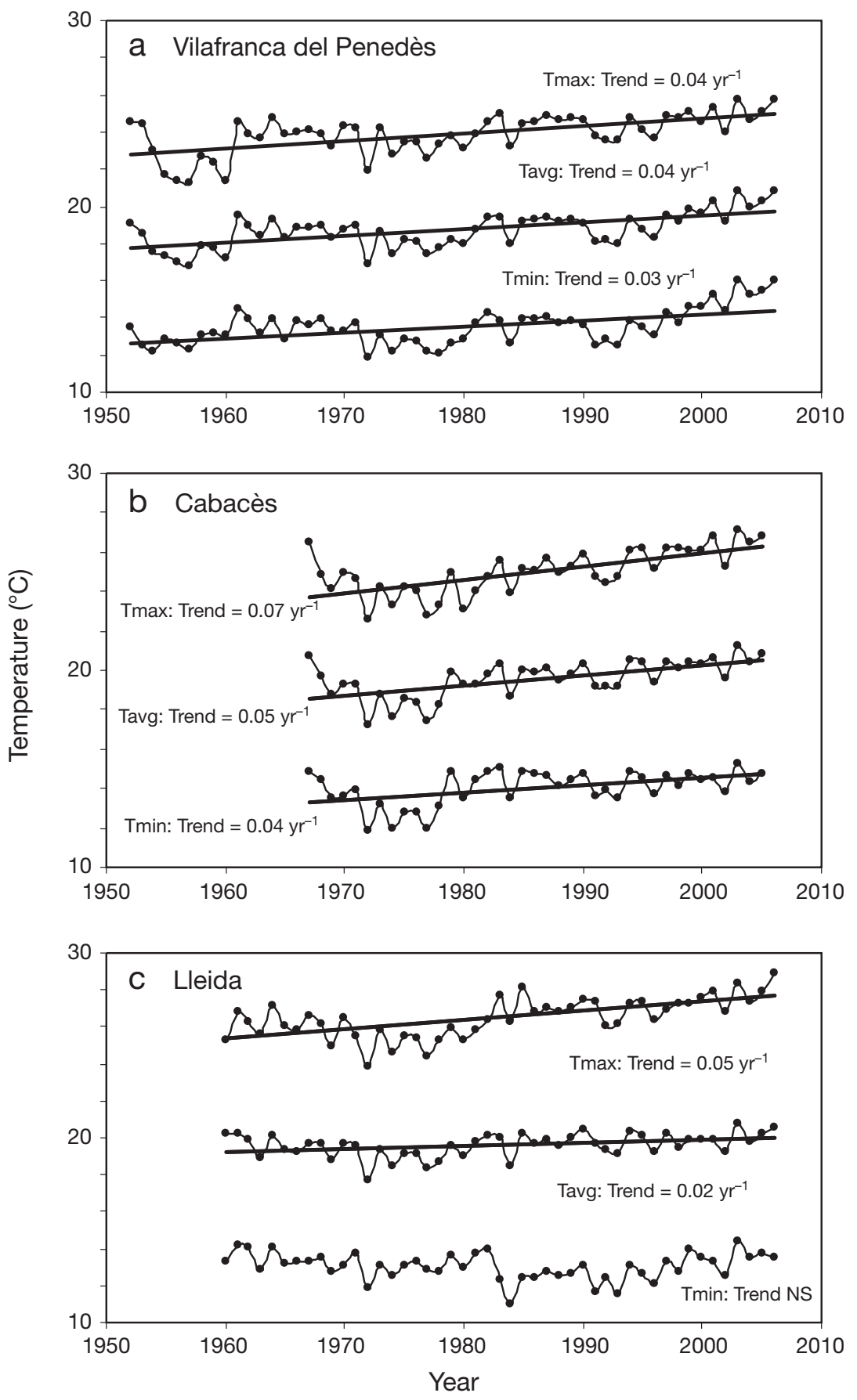

Fig. 2. Temperature trends (average, maximum, and minimum) during the growing season (Apr to Oct) in (a) Vilafranca del Penedès (1952-2006), (b) Cabacès (1967-2005), and (c) Lleida (1960-2006)

centile, significant decreasing trends were observed for maximum but not for minimum temperatures. Interestingly, while temperature increases were evident in the studied locations, the number of frost days showed a significant decreasing trend only in Vilafranca del Penedès, while changes in the frost-free period were not significant for any of the sites (Table 2).
Growing season maximum temperature extremes (days with $\mathrm{T}>25^{\circ} \mathrm{C}$ and $\mathrm{T}>30^{\circ} \mathrm{C}$ ) increased significantly in all 3 locations, with the average number of days with temperatures $>30^{\circ} \mathrm{C}$ being 18, 42, and 64 for Vilafranca del Penedès, Cabacès, and Lleida, respectively. Daytime maximum temperatures of $25-30^{\circ} \mathrm{C}$ are critical for optimum grapevine development. While a few days with temperatures $>30^{\circ} \mathrm{C}$ may be beneficial during the ripening period (Jones \& Davis 2000, White et al. 2006), too many days with temperatures $>30^{\circ} \mathrm{C}$ can induce plant stress, premature véraison, and reduction in photosynthesis (Mullins et al. 1992).

Often used to assess climate suitability for certain varieties and/or wine styles, the Winkler Index (WI) and Huglin Index (HI) are variations in degree-days, or heat accumulation formulas (Table 1). Trends in both parameters show significant changes at each location (Figs. 3 \& 4). The WI increased from 3.3 units $\mathrm{yr}^{-1}$ for Lleida [155 units $(47 \mathrm{yr})^{-1}$ ], 7.8 units $\mathrm{yr}^{-1}$ for Vilafranca del Penedès [429 units $\left(55 \mathrm{yr}^{-1}\right]$, and up to 11.2 units $\mathrm{yr}^{-1}$ for Cabacès [437 units $\left.(39 \mathrm{yr})^{-1}\right]$. These changes moves Vilafranca del Penedès from a high region II to a low region IV on the WI scale, Cabacès from a mid region III to a low region IV, and Lleida from the lower to higher range of region IV (Winkler et al. 1974).

Huglin Index (HI) trends were similar to the WI trends, although the changes were of greater relative magnitude since the HI gives more weight to maximum temperatures (Table 1) and GSTmax increased more significantly across sites (Table 2). Trends in the HI for Vilafranca del Penedès are 7.2 units $\mathrm{yr}^{-1}$ [396 units $\left(55 \mathrm{yr}^{-1}\right]$, while those for Cabacès and Lleida are 11.9 and 6.1 units $\mathrm{yr}^{-1}$ [464 units $\left(39 \mathrm{yr}^{-1}\right.$ and 287 units $(47 \mathrm{yr})^{-1}$ ], respectively. Greater change was observed in Cabacès which had a higher increase in GSTmax. These HI increases move Vilafranca del Penedès from a temperate to a warm climate type for winegrape production, Cabacès from warm temperate to warm, and Lleida from warm to very warm indicating potential variety shifts (Huglin 1978). Heat accumulation trends in other European wine regions have also increased, rising by 250-300 units over the last 30- 


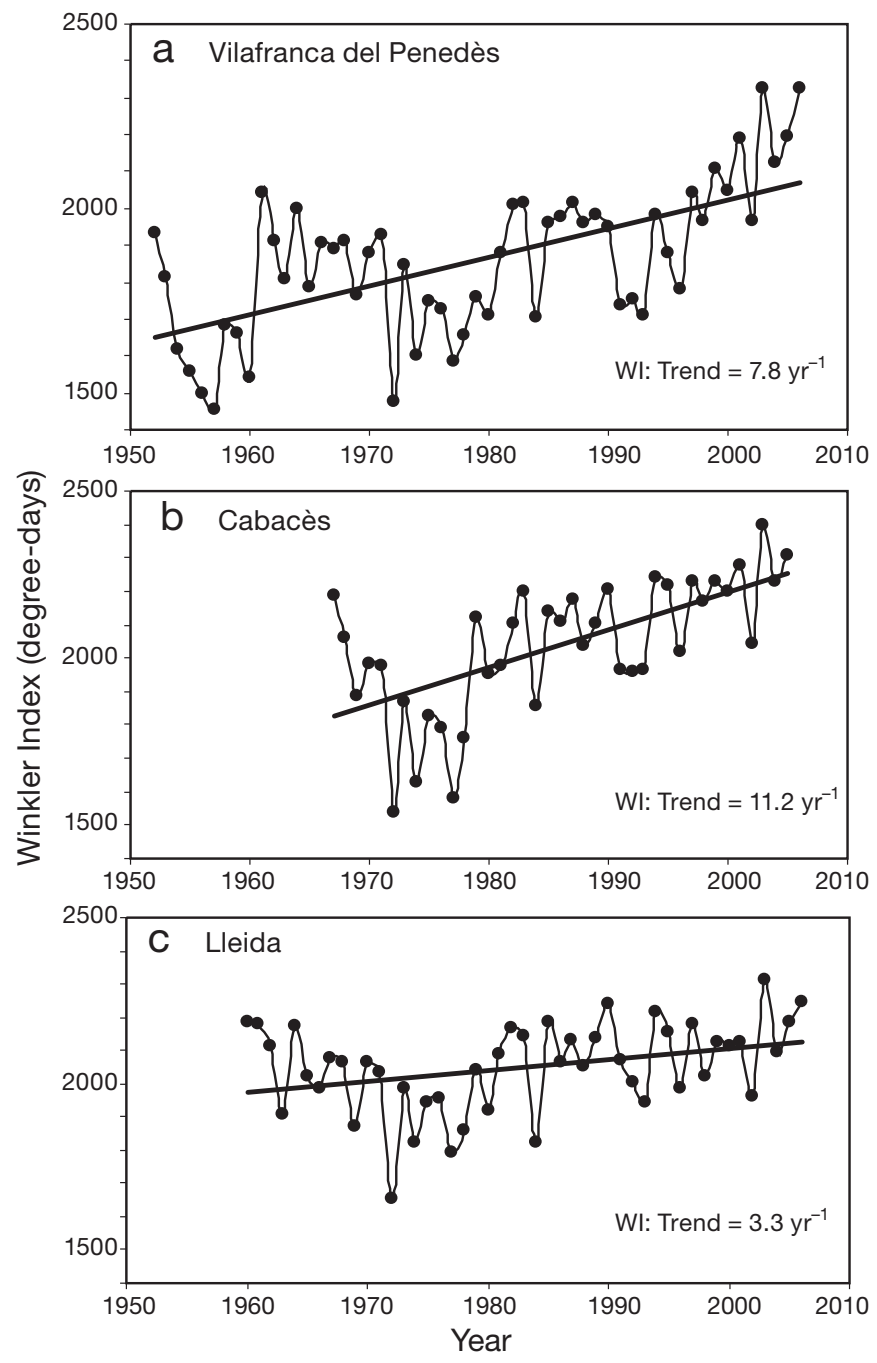

Fig. 3. Trends in the heat summation index (Winkler Index) for (a) Vilafranca del Penedès (1952-2006), (b) Cabacès (1967-2005), and (c) Lleida (1960-2006)

50 years (Jones et al. 2005b). In other areas in Spain, Jones et al. (2005b) reported increased heat accumulation (WI and HI) inland but not in the more coastal region of Galicia.

While growing season temperature changes were evident for the 3 locations studied, the diurnal temperature range during the ripening period (Aug to Sept) did not change significantly at 2 of the 3 stations (Table 2). This is due to differential changes in Tmax and Tmin during this period, which did not exhibit a coherent trend.

\subsection{Precipitation parameter trends}

The high interannual and intra-annual precipitation variability swamps any trend in majority of the pre-
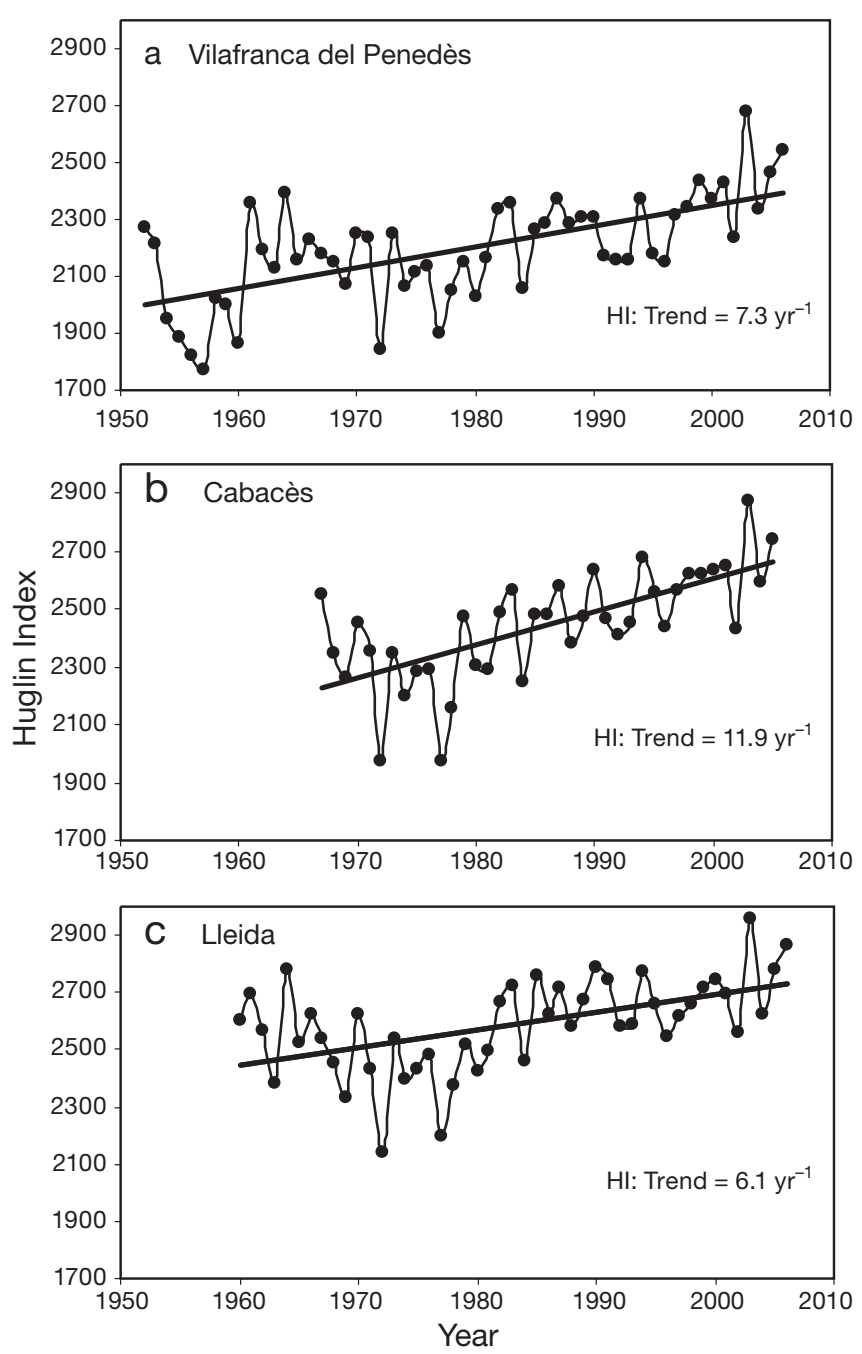

Fig. 4. Trends in the Huglin Index for (a) Vilafranca del Penedès (1952-2006), (b) Cabacès (1967-2005), and (c) Lleida (1960-2006)

cipitation parameters (Table 3). Annual and growing season precipitation did not change significantly in any of the sites. Vilafranca del Penedès was the only site that showed significant trends in the number of days with precipitation $>95$ th percentile as well as in the percentage of the annual precipitation received during these days (Table 3 ). This is a result of both high precipitation events and soil characteristics in the Penedès region (Ramos et al. 2000, Ramos \& Martínez-Casasnovas 2006b), where erosion events are frequently of high magnitude, and the increasing extremes will likely have additional negative impacts. Similar to this study, Jones et al. (2005b) found that precipitation frequency and amounts in other European wine regions have not changed significantly.

Given the critical nature of soil moisture for vine growth, a more detailed analysis of precipitation distri- 
bution during the phenological stages of vine development was conducted (Table 1). Results show that precipitation had opposite trends during the early stages of vine growth (Stages I \& II). During the budbreak to bloom stage (Stage I: April 1 to May 10), both Cabacès and Lleida tended to have wetter periods (Table 3). However, from bloom to véraison (Stage II: May 10 to June 30), each site experienced a significant decrease

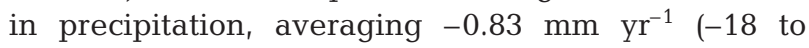
$-68 \mathrm{~mm}$ over the studied time periods). Peacock (2005) pointed out that water management is critical during Stage II and moisture stress during this stage could disrupt rapid cell division and result in significant dehydration and sunburn, which in combination can reduce berry size and yields.

Taking into account grapevine water needs and evapotranspiration during each stage, shorter-term data from 1996-2007 showed that crop evapotranspiration (ETc) in the study areas accounted for 11-12\% (Stage I), 28-29\% (Stage II), 44-47\% (Stage III), and 10-12\% (Stage IV) of the annual ETc (Table 4). Stage II precipitation amounts, on average, were below water requirements (ETc) and precipitation during this stage exhibited significant decreasing trends in all sites. Given that most temperature parameters increased significantly in all locations, particularly during the spring period (not shown), we estimate that the current ETc impact per $1{ }^{\circ} \mathrm{C}$ of growing season (Apr to Oct) warming increases water demands by $\sim 14 \%$ in Vilafranca and Cabacès, and $\sim 6 \%$ in Lleida. Similar results for crop water availability were found by Wang et al. (2006) in northeast China and by Neilsen et al. (2006) in British Columbia.

Table 4. Mean precipitation and crop evapotranspiration for the main phenological stages for 1996-2007 (I - budbreak to bloom; II - bloom to véraison; III - véraison to harvest; IV - post harvest; V - dormant period; ETc: crop evapotranspiration;

ETCS/ETcA: ETc of each stage as percent of annual ETc

\begin{tabular}{|lcrrc|}
\hline Station & Stage & $\begin{array}{r}\text { Prec. } \\
(\mathrm{mm})\end{array}$ & $\begin{array}{c}\text { ETc } \\
(\mathrm{mm})\end{array}$ & $\begin{array}{c}\text { ETcS/ETcA } \\
(\%)\end{array}$ \\
\hline La Granada & I & 72.0 & 56.1 & 12.6 \\
(Alt Penedès) & II & 60.7 & 127.6 & 28.4 \\
& III & 91.9 & 199.5 & 44.5 \\
& IV & 114.9 & 53.8 & 12.0 \\
& V & 165.7 & 10.9 & 2.4 \\
Margalef & I & 74.4 & 57.1 & 11.4 \\
(Priorat) & II & 46.1 & 127.7 & 28.0 \\
& III & 53.4 & 214.1 & 47.4 \\
& IV & 65.3 & 52.6 & 11.4 \\
Lleida-Raimat & V & 108.3 & 9.6 & 2.1 \\
(Segrià) & II & 65.5 & 55.3 & 11.5 \\
& III & 56.6 & 135.0 & 28.2 \\
& IV & 66.1 & 53.3 & 46.5 \\
& V & 142.5 & 12.8 & 11.2 \\
& & & & 2.5 \\
\hline
\end{tabular}

\subsection{Climate relationships with winegrape parameters}

Relationships of temperature, precipitation, and ETc parameters with grapevine phenology, wine quality, and wine production were examined for the available data from the 3 regions. In all cases, single-variable linear relationships of temperature with grapevine and wine parameters were found. Precipitation variables were less important except when summarized as a component of ET variables.

Grapevine phenology in the DO Penedès showed moderate to strong relationships with climate. Bloom and véraison showed the strongest relationship with temperature revealing negative correlations across all varieties (Macabeo, Xarello, Chardonnay, Parellada, and Pinot Noir. For example, Parellada véraison dates for 1996-2006 occurred earliest during growing seasons with warmer minimum temperatures $\left(\mathrm{R}^{2}=0.55\right.$; $-4.1 \mathrm{~d}$ per $1^{\circ} \mathrm{C}$ ) (Fig. 5a). While harvest dates in all regions showed less consistent relationships with lower significance, Chardonnay from 1997-2006 in the DO Costers del Segre revealed significantly earlier harvests during warmer growing seasons $\left(R^{2}=0.49\right.$; $-5.3 \mathrm{~d}$ per $1^{\circ} \mathrm{C}$ ) (Fig. $5 \mathrm{~b}$ ).

Vintage wine quality ranks for red wines from the DO Priorat for 1967-2005 showed the most significant relationship with ripening period (August and September) DTR (Fig. 5c). A greater DTR during ripening resulted in generally higher quality red wine in the DO Priorat $\left(+1^{\circ} \mathrm{C}\right.$ DTR results in a 0.4 rating point increase on a $1-5$ scale, $\mathrm{R}^{2}=0.22$ ). Similar results were found for the DO Penedès, although white wine quality ranks showed less significant relationships with DTR than did red wine quality ranks (not shown). For the DO Costers del Segre, wine quality ranks were not significantly related to DTR due to the short period covered by available data. However, increases in ripening period DTR may not always be positively related to wine quality, as a threshold is likely in which increases in Tmax during ripening would increase vine stress and water demand, as well as lower quality.

Production data $(\mathrm{hl})$ for the DO Penedès for the 1994-2006 period showed a moderately strong relationship with degree-days (WI) (Fig. 5d) in which lower production was typically seen in the warmest years $\left(-388,600 \mathrm{hl}\right.$ per $100 \mathrm{WI}$ units, $\left.\mathrm{R}^{2}=0.49\right)$. The impact varied for the main white varieties cultivated in the area: reductions of 915, 1420, and $729 \mathrm{~kg} \mathrm{ha}^{-1}$ per 100 WI units were observed for Macabeo $\left(\mathrm{R}^{2}=0.40\right)$, Parellada $\left(\mathrm{R}^{2}=0.50\right)$, and Xarello $\left(\mathrm{R}^{2}=0.36\right)$, respectively, while the relationship was not significant for Chardonnay (not shown). Similar production data was not available for the other 2 regions. 

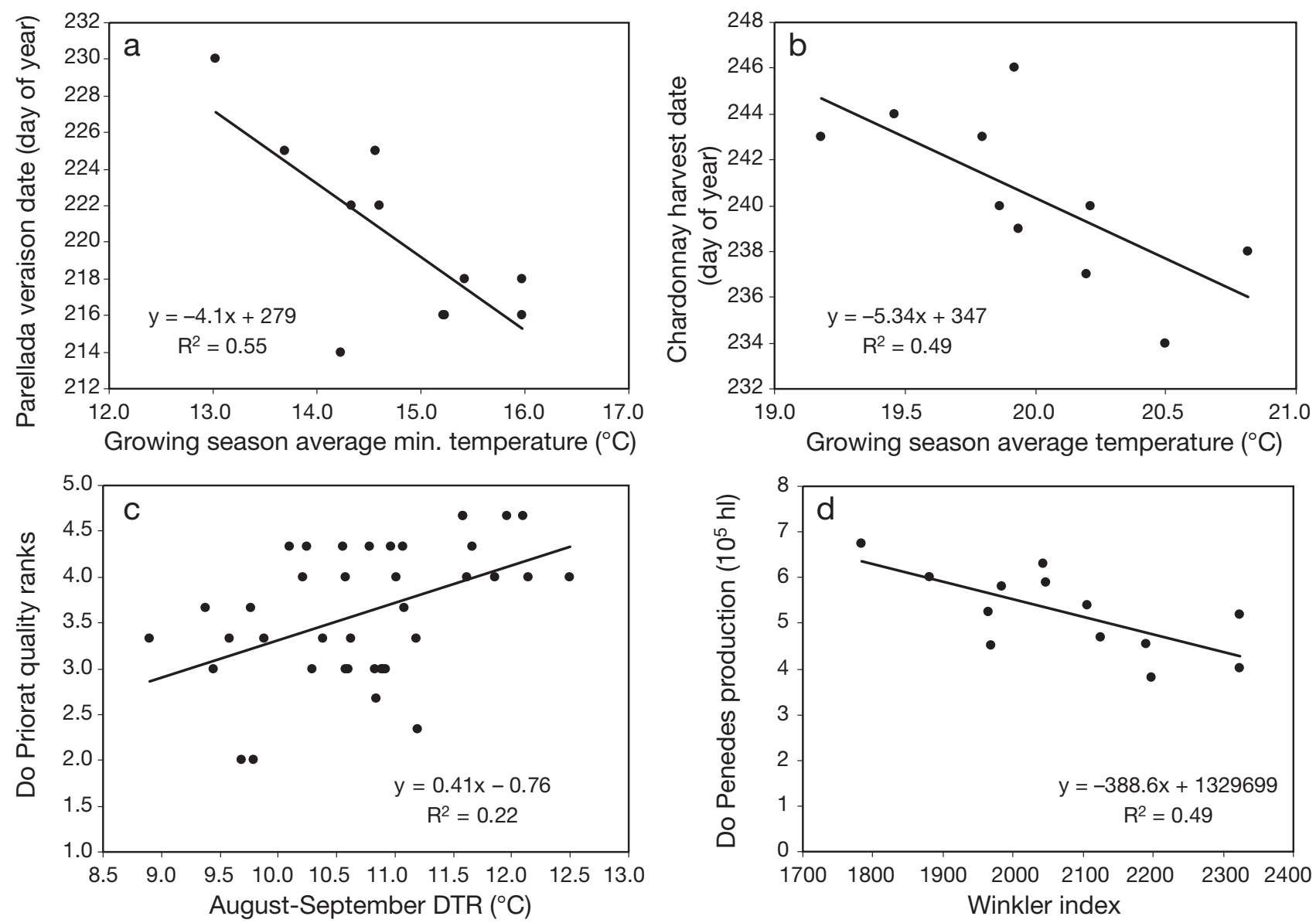

Fig. 5. (a) Growing season (April to October) average minimum temperature versus Parellada véraison date in the DO Penedès, (b) growing season average temperature versus Chardonnay harvest date in the DO Costers del Segre, (c) ripening diurnal temperature range in August to September versus DO Priorat quality ranks, and (d) Winkler Index versus DO Penedès production

\section{DISCUSSION AND CONCLUSIONS}

The climate structure in the NE Spanish regions of Alt Penedès, Priorat, and Segrià is strongly Mediterranean with hot, dry summers that place them in the upper warm to hot climate-maturity types for winegrape production (Jones 2006). Trends in these regions indicate average growing season warming of $0.02,0.04$, and $0.05^{\circ} \mathrm{C} \mathrm{yr}^{-1}$ in Lleida, Vilafranca del Penedès, and Cabacès, respectively. Over the time periods studied, this represents a change of $1.0^{\circ} \mathrm{C}$ in Lleida, $2.2^{\circ} \mathrm{C}$ in Vilafranca del Penedés and $2.0^{\circ} \mathrm{C}$ in Cabacès (Table 2). Similar trends have been seen in other areas of Spain (del Rio et al. 2007), in other winegrowing regions in Europe (Jones et al. 2005b), and across the majority of the world's best wine regions (Jones et al. 2005a). The average growing season warming rates for the 3 analysed stations in NE Spain are driven more by changes in maximum temperatures, in which significant increases in the number of days with temperatures $>95$ th percentile have been observed. Del Rio et al. (2007) found similar results for NW Spain (Castilla y Leon) for 19611997 as did Brunet et al. (2007), who examined a record from 1850-2005 for 22 stations in Spain. In each case, maximum temperatures increased at a higher rate than minimum temperatures, producing an increase in the annual diurnal temperature range. Brunet et al. (2007) also found declines in the number of moderately extreme cold days (Tmax $<10$ th percentile) and moderately extreme cold nights (Tmin < 10th percentile), and increases in moderately extreme warm days and nights (Tmax and Tmin > 90th percentile) of the same magnitude as found in this study. In contrast, minimum temperatures have shown more significant rates of warming in wine regions in the USA (Jones 2005) and Europe (Jones et al. 2005b), which may be related to greater irrigation or higher ambient moisture (Christy et al. 2006).

Temperature trends in the 3 studied regions have led to significant changes in the Winkler and Huglin heat accumulation indices. The WI increase from 155 to 
437 units (Table 2) suggests shifts in classification of regions from those suited to early and mid-season table wine varieties for high production, and good to standard quality wines, to those where table wine quality will be acceptable at best. Similarly, the HI increase from 287 to 464 units (Table 2) moves Vilafranca del Penedès from a temperate to a warm climate type for winegrape production, Cabacès from warm temperate to warm, and Lleida from warm to very warm, indicating varietal suitability shifts (Huglin 1978). Heat accumulation trends in other European wine regions have also increased, rising by 250-300 units over the last 30-50 years (Jones et al. 2005b, Duchêne \& Schneider 2005).

For precipitation, high variability from year to year is evident in all 3 locations. Extreme precipitation events also exhibited high temporal variability, although Vilafranca del Penedès (the more maritime location) showed significant increases in the number of days with extreme precipitation and in the maximum precipitation recorded in $24 \mathrm{~h}$ (Table 3). The significant trends of decreasing precipitation during bloom to véraison at the 3 locations (Table 3) were similar to results reported by Sumner et al. (2001) for Spain in general and specifically for Catalonia in 1964-1993, when there were indications of a greater concentration of cool season precipitation, and some evidence of warm season drying. These declines are critical, since vines at this growth stage (bloom to véraison) should have adequate access to soil moisture and not be exposed to high water stress. During the last decade, high water deficits have been observed in the studied regions, with precipitation providing only $\sim 25-30 \%$ of water needs during the bloom to véraison stage. In areas where irrigation water is not available, this will impose water restrictions on growth and impact the ability of the grapevines to undergo normal ripening.

Earlier phenological timing and shortening of the growing and ripening periods have been observed in many regions globally and are significantly related to temperature increases (Jones et al. 2005b). Chuine et al. (2004), examining a $\sim 700 \mathrm{yr}$ record of harvest dates for Burgundy, found that harvest is on average $10 \mathrm{~d}$ earlier per $1{ }^{\circ} \mathrm{C}$ warming during the growing season, while Jones et al. (2005b) found that phenologytemperature relationships over the last 30-50 yr for numerous varieties and locations in Europe show a 3-6 d response per $1^{\circ} \mathrm{C}$ of warming (weaker response for early season events such as bud break). For the 3 studied regions in NE Spain, overall results were similar, with warmer growing seasons bringing earlier bloom, véraison, and harvest dates. For the Penedès region, limited data from 1996-2007 provided by 5 producers showed that véraison and harvest dates for 3 of the main varieties grown there-Macabeo, Parel- lada, and Xarello - advanced by 3-7 d per $1^{\circ} \mathrm{C}$ warming during the growing season. Similar results were found for the Lleida region, where harvest dates of 8 varieties show moderate to strong relationships with growing season temperatures (Fig. 5d).

Wine production data, which was limited to the Alt Penedès for the 1994-2006 period, show generally lower production during warmer growing seasons with earlier phenological timing (Fig. 5a,d), which is likely due to volume loss from a combination of heat and lack of water (Mullins et al. 1992). Earlier harvests in these regions show a significant inverse relationship between precipitation and temperature during the Stage II growth period (bloom to véraison). Over the last decade, yield data provided by 2 large producers in Alt Penedès for Macabeo and Chardonnay varieties reveal an average reduction of $200-320 \mathrm{~kg} \mathrm{ha}^{-1}$ following a precipitation decrease of $10 \mathrm{~mm}$ during Stage II (authors' unpubl. data). In Priorat, data from 2 producers reveal that Grenache yields declined by an average of $130 \mathrm{~kg} \mathrm{ha}{ }^{-1}$ with a decrease in precipitation of $10 \mathrm{~mm}$ during Stage II. In addition, sugar and alcohol concentration may be expected to increase due to berry volume reduction (Mullins et al. 1992, Jones 2007). Where water for irrigation is available, as in the Segre River valley (Lleida), loss of yield and unbalanced fruit composition may be partially controlled, but at a higher cost.

Warmer growing seasons, which result in earlier phenological events and lower production, also tend to result in higher quality. However, the results are not as strong for white wines, as they are for red wines, and not as evident in the Penedès, where Cava or sparkling wines are more prominent than in the Priorat, where red wines are more important. The most significant climate parameter for red wine quality in the Priorat is the diurnal temperature range during ripening (August and September) (Fig. 5c), in which higher amplitudes result in more consistently higher rated vintages. However, the DTR for the studied locations during this period did not exhibit significant trends, indicating that year to year variations in ripening climates have pronounced effects on potential wine quality.

Although the results for grapevine phenology, production, and quality are limited to short time periods, we are confident that the analysis revealed underlying relationships that exist in the regions. Moreover, the similarity in the relationships of climate with grapevine phenology, wine production, and wine quality observed here and those in other studies in Spain and Europe (Jones \& Davis 2000, Jones et al. 2005b, Blanco-Ward et al. 2007) indicate the robustness of the results, which could be enhanced if longer time periods were analyzed. Longer time periods of wine- 
related parameters might help reveal the optimum climate structure for wine production and quality.

In terms of future climate, Jones et al. (2005a) projected that growing season temperatures in the majority of the world's best wine regions will continue to warm by an average of $2.0^{\circ} \mathrm{C}$ by 2050 . Other regional work in Europe (Kenny \& Harrison 1992, Stock 2005), Australia (McInnes et al. 2003, Webb et al. 2005), and South Africa (Carter 2006) examined climate change using different modeling approaches and gave similar results. Kenny \& Harrison (1992) indicated potential shifts and/or expansions in the geography of viticulture regions with parts of southern Europe predicted to become too hot to produce high quality wines and northern regions becoming viable once again. Stock (2005) showed HI increases of 100-600 units that result in broad latitudinal shifts, making new areas on the northern fringes viable, changing varietal suitability in existing regions, and rendering southern regions too hot for overall suitability. Specifically in Spain, Moreno-Rodriguez (2005) examined different emission scenarios and found increases of $0.4-0.7^{\circ} \mathrm{C}$ per decade, with warming in summer being greater than in winter. Overall, the projected changes in Spain result in warming of $5-7^{\circ} \mathrm{C}$ inland and $3-5^{\circ} \mathrm{C}$ along the coast by 2100 . Concomitant with these temperature projections, Moreno-Rodriguez (2005) also predicted much drier springs and summers and lower annual rainfall, which is less homogeneous than temperature across Spain. Furthermore, modeling of grapevine phenology for Syrah in France predicted earlier start of ripening by $3-5$ wk with a $2-4^{\circ} \mathrm{C}$ warming (Lebon 2002), and that Cabernet Sauvignon in Coonawarra, Australia would be harvested up to $45 \mathrm{~d}$ earlier by 2050 (Webb et al. 2007). Additionally, these studies reported disruption in flavor and color development with significant warming during maturation and especially at night, ultimately upsetting wine typicity and quality.

For the Segrià, Alt Penedès, and Priorat regions of NE Spain, the historic climate structure has been well suited to quality wine production. The recent trends challenge this suitability. From rising average growing season temperatures, to increases in maximum temperature extremes, and declining precipitation during Stage II (bloom to véraison), the climates of these areas have significantly changed over the last 39-55 yr. Climate projections for Spain indicate that these trends are likely to continue (Moreno-Rodriguez 2005), further exasperating growing conditions and water availability, and ultimately affecting wine production and quality potential. Further warming may result in varietally specific optimum climates being exceeded such that the ability to ripen balanced fruit from the existing varieties grown and the production of current wine styles will become more challenging.
Acknowledgements. This research was developed in the framework of the Project AGL2005-00091/AGR financed by the CICYT (Programa Nacional de Tecnologías y Recursos Agroalimentarios). The authors thank wine producers for the information about their vineyards.

\section{LITERATURE CITED}

Adams RM, Chen CC, McCarl BA, Schimmelpfennig DE (2001) Climate variability and climate change: implications for agriculture. Adv Econ Environ Resour 3:95-113

Alexandersson H (1986) A homogeneity test applied to precipitation data. J Climatol 6:661-675

Allen RG, Pereira LS, Raes D, Smith M (1998) Crop evapotranspiration. Guidelines for computing crop water requirements. FAO Irrigation and Drainage Paper No. 56. Food and Agriculture Organization, Rome

Bayazit M, Önöz B (2007) To prewhiten or not to prewhiten in trend analysis? Hydrol Sci J 52:611-624

Beniston M, Tol RSJ (1998) Europe. In: Watson RT, Zyinyowera MC, Moss RH (eds) The regional impacts of climate change. An assessment of vulnerability. IPCC, Cambridge University Press, p 149-185

Blanco-Ward D, Garcia-Queijeiro JM, Jones GV (2007) Spatial climate variability and viticulture in the Miño River Valley of Spain. Vitis 46:63-70

Bonell M, Sumner G (1992) Autumn and winter daily precipitation areas in Wales, 1982-1983 to 1986-1987. Int J Climatol 12:77-102

Brunet M, Jones PD, Sigró J, Saladié O and others (2007) Temporal and spatial temperature variability and change over Spain during 1850-2005. J Geophys Res 112: D12117

Brunetti M, Maugeru M, Nanni T, Navarra A (2002) Droughts and extreme events in regional daily Italian precipitation series. Int J Climatol 22:543-558

Carter S (2006) The projected influence of climate change on the South African wine industry. Interim Report IR-06-043, International Institute for Applied Systems Analysis, Laxenburg

Chloupek O, Hrstkova P, Schweigert P (2004) Yield and its stability, crop diversity, adaptability and response to climate change, weather and fertilisation over 75 years in the Czech Republic in comparison to some European countries. Field Crops Res 85:167-190

Christy JR, Norris WB, Redmond K, Gallo KP (2006) Methodology and results of calculating Central California surface temperature trends: evidence of human-induced climate change? J Clim 19:548-563

Chuine I, Yiou P, Viovy N, Seguin B, Daux V, Le Roy Ladurie E (2004) Grape ripening as a past climate indicator. Nature 432:289-290

Coombe BG (1987) Influence of temperature on composition and quality of grapes. Acta Hortic 206:23-35

del Río S, Fraile R, Herrero L, Penas A (2007) Analysis of recent trends in mean maximum and minimum temperatures in a region of the NW of Spain (Castilla y León). Theor Appl Climatol 90:1-12

Díaz-Jiménez J, Linares-Gil C, García-Herrera R (2005) Impact of extreme temperatures on public health (Impacto de las temperaturas extremas en la salud pública: futuras actuaciones). Rev Esp Salud Publ 79:145-157

> Douglas EB, Vogel RM, Knoll CN (2000) Trends in floods and low flows in the United States: impact of serial correlation. J Hydrol (Amst) 240:90-105

Duchêne E, Schneider C (2005) Grapevine and climatic 
changes: a glance at the situation in Alsace. Agron Sustain Dev 25: 93-99

Easterling DR, Evans JL, Groisman PYa, Karl TR, Kunkel KE, Ambenje P (2000a) Observed variability and trends in extreme climate events: a brief review. Bull Am Meteorol Soc 81:417-425

Easterling DR, Meehl GA, Parmensan C, Chagnon SA, Karl T, Mearns LO (2000b) Climate extremes: observation, modelling and impacts. Science 289:2068-2074

Ebi KL, Mills DM, Smith JB, Grambsch A (2006) Climate change and human health impacts in the United States: an update on the results of the U.S. National Assessment. Environ Health Perspect 114:1318-1324

Fischer G, Shah M, van Velthuizen H (2002) Climate change and agricultural vulnerability. International Institute for Applied Systems Analysis. Report prepared under UN Institutional Contract Agreement 1113 for World Summit on Sustainable Development, Laxenburg

Greene JS, Maxwell E (2007) Climatic impacts on winter wheat in Oklahoma and potential applications to climatic and crop yield prediction. Int J Biometeorol 52:117-126

Hidalgo L (2002) Tratado de viticultura general, 3rd edn. Mundi-Prensa, Madrid

Hirsch RM, Alexander RB, Smith RA (1991) Selection of methods for the detection and estimation of trends in water quality. Water Resour Res 27:803-813

Huglin P (1978) Nouveau mode d'évaluation des possibilités héliothermiques d'un milieu viticole. In: Proc Symp Int sur l'ecologie de la Vigne. Ministère de l'Agriculture et de l'Industrie Alimentaire, Contança, p 89-98

IPCC (2007) Climate change 2007: the physical science basis. In: Solomon S, Qin D, Manning M, Chen Z, Marquis M, Averyt KB, Tignor M, Miller HL (eds) Contribution of working Group I to the fourth sssessment report of the Intergovernmental Panel on Climate Change. Cambridge University Press, p 18

Jones GV (2005) Climate change in the western United States grape growing regions. Acta Hortic 689:41-60

Jones GV (2006) Climate and terroir: impacts of climate variability and change on wine. In: Macqueen RW, Meinert LD (eds.) Fine wine and terroir-The geoscience perspective. Geoscience Canada Reprint Series No. 9, Geological Association of Canada, St. John's, Newfoundland, p 247

Jones GV (2007) Climate change and the global wine industry. In: Blair R, Williams P, Pretorius S (eds) Proc 13th Australian Wine Ind Tech Conf, Adelaide, Australia, p 91-98

> Jones PD, Conway D (1997) Precipitation in the British Isles: an analysis of area-average data updated to 1995. Int J Climatol 17:427-438

Jones GV, Davis RE (2000) Climate influences on grapevine phenology, grape composition, and wine production and quality for Bordeaux, France. Am J Enol Vitic 51:249-261

Jones GV, White MA, Cooper OR, Storchmann K (2005a) Climate change and global wine quality. Clim Change 73: 319-343

Jones GV, Duchêne E, Tomasi D, Yuste J and others (2005b) Changes in European winegrape phenology and relationships with climate. GESCO (Groupe d'Etude des Systèmes de Conduite de la Vigne)

Karl TR (1998) Regional trends and variations of temperature and precipitation. In: Watson RT, Zyinyowera MC, Moss $\mathrm{RH}$ (eds) The regional impacts of climate change. An assessment of vulnerability. IPCC, Cambridge University Press, p 411-437

Kenny GJ, Harrison PA (1992) The effects of climate variability and change on grape suitability in Europe. J Wine Res 3:163-183
Kenny GJ, Harrison PA, Parry ML, Porter JR (1993) The effects of climate change on agriculture and horticulture in Europe. Eur J Agron 2:243-246

Kiktev DB, Sexton DMH, Alexander LV, Folland CK (2002) Trends in fields of precipitation and surface temperature annual extremes during the second half of the 20th century. Russ Meteorol Hydrol 11:7-16

Klein Tank AMG, Können GP (2003) Trends in indices of daily temperature and precipitation extremes in Europe, 1946-99. J Clim 16:3665-3680

> Lana X, Serra C, Burgueno A (2003) Trends affecting pluviometric indices at the Fabra observatory (Barcelona, NE Spain) from 1917 to 1999. Int J Climatol 23:315-332

Lebon E (2002) Changements climatiques: quelles conséquences pour la viticulture. CR 6ième Rencontres Rhodaniennes, p 31-36

Lee SE, Press MC, Lee JA (2000) Observed climate variations during the last 100 years in Lapland, Northern Finland. Int J Climatol 20:329-346

> Libiseller C, Grimvall A (2002) Performance of partial MannKendall test for trend detection in the presence of covariates. Environmetrics 13:71-84

> Lobell DB (2007) Changes in diurnal temperature range and national cereal yields. Agric For Meteorol 145:229-238

> Lobell DB, Cahill KN, Field CB (2007) Historical effects of temperature and precipitation on California crop yields. Clim Change 81:187-203

- Maracchi G, Sirotenko O, Bindi M (2005) Impacts of present and future climate variability on agriculture and forestry in the temperate regions: Europe. Clim Change 70:117-135

Martínez-Casasnovas JA, Ramos MC, Ribes-Dasi M (2002) Soil erosion caused by extreme rainfall events: mapping and quantification in agricultural plots from very detailed digital elevation models. Geoderma 105:125-140

McInnes KL, Whetton PH, Webb L, Hennessy KJ (2003) Climate change projections for Australian viticultural regions. The Australian and New Zealand Grapegrower and Winemaker, February 2003, p 40-47

> Michael A, Schmidt J, Enke W, Deutschländer Th, Malitz G (2005) Impact of expected increase in precipitation intensities on soil loss - results of comparative model simulations. Catena 61:155-164

Ministerio de Agricultura Pesca y Alimentación (MAPA) (2005) Datos de los vinos de calidad producidos en regiones determinadas (vcprd) campaña 2004-2005. p 56

Moreno-Rodriguez JM (2005) Main conclusions from the preliminary assessment of the impacts in Spain due to the effects of climate change. Project ECCE, Ministry of the Environment and the University of Castilla-La Mancha, p 39

Mullins MG, Bouquet A, Williams LE (1992) Biology of the grapevine. Cambridge University Press, p 239

Neilsen D, Smith CAS, Frank G, Koch W and others (2006) Potential impacts of climate change on water availability for crops in the Okanagan Basin, British Columbia. Can J Soil Sci 86:921-936

> Osborn TJ, Hulme M, Jones PD, Basnett TA (2000) Observed trends in the daily intensity of United Kingdom precipitation. Int J Climatol 20:347-364

Peacock B (2005) Water management for grapevines. Tulare County Grape Publications, Publ. \# IG1-95. http:// cetulare.ucdavis.edu/pubgrape/pubgrape.htm

Peterson TV, Folland C, Gruza G, Hogg W, Mokssit A, Plummer N (2001) Report on the activities of the Working Group on climate change detection and related rapporteurs 1998-2001. World Meteorological Organisation Rep WCDMP-47, WMO-D 1071, Geneva, Switzerland, p 143 
Ramos MC (2001) Rainfall distribution patterns and their change over time in a Mediterranean area. Theor Appl Climatol 69:163-170

Ramos MC, Martínez-Casasnovas JA (2006a) Trends in precipitation concentration and extremes in the Mediterranean Penedès-Anoia region, NE Spain. Clim Change 74:457-474

Ramos MC, Martínez-Casasnovas JA (2006b) Nutrient losses by runoff in vineyards of the Mediterranean Alt Penedès region (NE Spain). Agric Ecosyst Environ 113:356-363

Ramos MC, Nacci S, Pla I (2000) Soil sealing and erosion rates of some soils from the Mediterranean area. Soil Sci 165: 398-403

Ramos MC, Cots-Folch R, Martínez-Casasnovas JA (2007) Sustainability of land terracing in the new field organisation of the Priorat region (NE, Spain). Geomorphology 86:1-11

Rochette P, Belanger G, Castonguay Y, Bootsma A, Mongrain D (2004) Climate change and winter damage to fruit trees in eastern Canada. Can J Plant Sci 84:1113-1125

Salinger MJ (2005) Climate variability and change: past, present and future-an overview. Clim Change 70:9-29

Stock M (2005) Klimaveränderungen fordern die WinzerBereitschaft zur Anpassung ist erforderlich. Geisenheimer Berichte 57:29-48

Sumner G, Homar V, Ramis C (2001) Precipitation seasonality in eastern and southern coastal Spain. Int J Climatol 21: $219-247$

Editorial responsibility: Nils Chr. Stenseth, Oslo, Norway
Todisco F, Vergni L (2008) Climatic changes in Central Italy and their potential effects on corn water consumption. Agric For Meteorol 148:1-11

von Storch H (1995) Misuses of statistical analysis in climate research. In: von Storch H, Navara A (eds) Analysis of climate variability: applications of statistical techniques. Springer-Verlag, Berlin, p 11-26

Wang H, Xu S, Sun L (2006) Effects of climatic change on evapotranspiration in Zhalong Wetland, Northeast China. Chin Geogr Sci 16:265-269

Webb LB, Whetton PH, Barlow EWR (2005) Impact on Australian viticulture from greenhouse induced temperature change. In: Zerger A, Argent RM (eds) MODSIM 2005 International Congress on Modelling and Simulation. Modelling and Simulation Society of Australia and New Zealand, Melbourne, p 170-176

Webb LB, Whetton PH, Barlow EWR (2007) Modelled impact of future climate change on the phenology of winegrapes in Australia. Aust J Grape Wine Res 13:165-175

White MA, Diffenbaugh NS, Jones GV, Pal JS, Giorgi F (2006) Extreme heat reduces and shifts United States premium wine production in the 21st century. Proc Natl Acad Sci USA 103:11217-11222

Winkler AJ, Cook JA, Kliewer WM, Lider LA (1974) General viticulture. University of California Press, Berkeley

Zhang X, Harvey KD, Hogg WD, Yuzyk TR (2001) Trends in Canadian streamflow. Water Resour Res 37:987-998

Submitted: February 8, 2008; Accepted: July 24, 2008 Proofs received from author(s): September 8, 2008 